CONGENITAL SYPHILIS

By David Nabarro, M.D., F.R.C.P. Pp. xi + 470, with 95 illustrations. London: Edward Arnold Ltd. I954. 50s.

This monograph is based on nearly a thousand cases of congenital syphilis under the age of 12 which were dealt with by the author between 1917 and 1939 when he was in charge of the Venereal Diseases Clinic at the Hospital for Sick Children, Great Ormond Street, London. He discusses fully every aspect of the disease, rare or commonplace, and gives at length the views of many other writers both ancient and modern.

$\mathrm{He}$ is not dogmatic in his own conclusions, therefore, though one can strongly recommend this book to the expert, one would advise the less experienced to read the modern standard textbooks first.

He describes many cases the like of which may never be seen again in this country, but may well be met with in less civilized lands. Unfortunately, it cannot be helped that modern colour photography was not available when these patients were seen.

One whose working life ended in I 939 cannot be expected to have much first-hand knowledge of the great therapeutic advances of the last ten years and consequently his views on treatment are not quite up to date.

The historical chapter is particularly interesting and the references in the text and at the end of each chapter are most comprehensive and will be of great value to future authors.

The book is very well produced and the arrangement and index are excellent.

$$
\text { F.J.G.J. }
$$

\section{CLINICAL CHEMISTRY IN PRACTICAL MEDICINE}

By C. P. Stewart, D.Sc., PL.D. and D. M. Dunlop, B.A., M.D., F.R.C.P. 4th Edition. Pp. vii +320 , with 27 illustrations. Edinburgh: E. \& S. Livingstone, Ltd.. r 954.2 rs.

This is an excellent book which can be thoroughly recommended to all who cannot spare the time to read a large text book. The information is clearly presented, with a practical emphasis everywhere. Appendices give concise descriptions of actual methods and tables of normal values. It is difficult to find anything that can be adversely criticised : future editions might contain a fuller and more accurate account of 'Water Retention' and describe the diagnosis and treatment of electrolyte abnormalities complicating the modern treatment of Congestive Failure. The Low Salt Syndrome deserves a section to itself. 'Plasma Potassium' could be extended from 16 lines to a page or twoperhaps at the expense of the 20 pages devoted to that anachronism the Fractional Test Meal. More space might also be given to the Electrophoresis (and the chromatography) of Proteins and the clinical use of I I 3 r. Osteoporosis and Osteomalacia are curiously confused (Albright's usage is at least clear). The estimation of blood sugars in the fasting state and two hours after ingestion of $50 \mathrm{~g}$. glucose, as a substitute for the glucose $\frac{z}{z}$ tolerance test, would save clinical laboratories many hours of work. Lastly, the value of any book of this size is greatly increased by the inclusion of a few well-chosen references at the end of each chapter.

\section{SURGERY OF THE CAECUM AND COLON}

By. Stanley AyletT, M.B.E., M.B., B.S., B.Sc., F.R.C.S. Pp. viii +295 , with 142 illustrations. Edinburgh: E. \& S. Livingstone, Ltd. 1954. 45s.

Mr. Aylett's monograph is orderly in its content and reasonable in its emphasis. Although based primarily on a wide personal experience, there is ample reference to the work of others. The operative descriptions, even if tediously repetitive (this in a commendable effort to avoid cross reference), are none the less clear and the illustrations with which it abounds, are wholly excellent. The reproductions of photographs and of X-rays, the type, the paper and the lay-out are of the quality which we have now come to expect from the House of Livingstone.

Mr. Aylett has always been the champion of ileorectal anastomosis in the treatment of multiple polyposis and of ulcerative colitis. Even if we are not convinced by his arguments, we must allow that he pleads his case again with the same vigouf and enthusiasm as he does in surgical debate.

But the shortcomings of this book are none the less obvious. The quite inexcusably large number of typographical errors will surely disappear in a further edition and we can only hope that many of the ugly words, to which we too readily give acceptance in medical phraseology, will be quietly effaced. To 're-peritonealize,' 'epithelialized ' and 'diathermied ' we have almost become accustomed, but we must surely draw the line at "bowel sterilisant,' ' stricturing,' ' intussuscepted,' ' dilative ' and 'irresectable.'

Our main quarrel, however, is that the text is far too long; it could with profit be rigorously pruned. Surely arguments are none the less telling when they are short and to the point.

In the opening paragraph of the preface the author expresses the hope ' . . . that the pages which follow may fill a genuine gap on the over-burdened bookshelves of medical literature.' This volume can fairly he said to have filled the gap, but at the same time to have added quite unnecessarily to the burden.

M.R.E.

\section{MANSON'S TROPICAL DISEASES}

Edited by Sir Philip H. Manson-Bahr, C.M.G., D.S.O., M.A., M.D., D.T.M. \& H., F.R.C.P. I4th edition. Pp. xiv + I I44, with 440 illustrations, 15 in colour. London: Cassell \& Co., Ltd. r 954 . 6os.

It is 56 yisars since the first edition of this work 